\title{
Anatomy of the female reproductive system and sperm storage of the viviparous caecilian Typhlonectes natans (Gymnophiona: Typhlonectidae)
}

\author{
JAKUB DYMEK, ${ }^{1}$ ANNA DYMEK, ${ }^{2}$ ARTUR OSIKOWSKI ${ }^{3}$
} ${ }^{1}$ Department of Comparative Anatomy, Institute of Zoology and Biomedical Research, Jagiellonian University, Gronostajowa 9,
30-387 Kraków, Poland, e-mail address: kuba.dymek@doctoral.uj.edu.pl
${ }^{2}$ Department of Comparative Anatomy, Institute of Zoology and Biomedical Research, Jagiellonian University, Gronostajowa 9,
30-387 Kraków, Poland, e-mail address: anna.tyrkalska@doctoral.uj.edu.pl
${ }^{3}$ Department of Animal Anatomy, Institute of Veterinary Science, University of Agriculture in Krakow. Al. Mickiewicza 24/28,
30-059 Kraków, Poland, e-mail address: a.osikowski@ur.krakow.pl

Keywords Typhlonectes, Gymnophiona, reproductive system, viviparity, sperm storage

Abstract Here, we describe the anatomy of the female reproductive system of the aquatic, viviparous caecilian Typhlonectes natans. We conducted our research on two adult females using light microscopy and reflected our results with the available literature data on the anatomy of the reproductive systems of caecilian amphibians. The female reproductive system of T. natans consisted of longitudinal, paired ovaries incorporated with fat bodies, paired oviducts and the cloaca. The ovaries were arranged in segmental mannered germinal nests and the oocytes were in various stages of development. Ovulated, postvitellogenic oocytes were present in the oviducts of both females. The wall of the oviduct consisted of three layers: the mucous membrane, layers of muscles and serous membrane. The presence of wedge-like cells, not previously reported in the mucous membrane of the caecilian oviduct is postulated. Although the females possessed ovulated eggs, no sperm were detected in any part of the oviducts leaving the question of eventual female sperm storage in Typhlonectes natans open.

\section{Anatomia żeńskiego układu rozrodczego oraz system przechowywania nasienia żyworodnego płaza beznogiego Typhlonectes natans (Gymnophiona: Typhlonectidae)}

Słowa kluczowe Typhlonectidae, płazy beznogie, układ rozrodczy, żyworodność, przechowywanie plemników

Streszczenie

W artykule opisano budowę anatomiczną żeńskiego układu rozrodczego żyworodnego płaza beznogiego Typhlonectes natans. Badania z wykorzystaniem mikroskopii świetlnej przeprowadzono na dwóch dojrzałych samicach. Otrzymane wyniki porównano z danymi literaturowymi dotyczącymi żeńskiego układu rozrodczego płazów beznogich. U T. nantans składa się on z wydłużonych, parzystych jajników oraz parzystych jajowodów uchodzących do kloaki. W pobliżu jajowodów znajdują się wydłużone ciała tłuszczowe. Segmentowane jajniki zawierają gniazda oogoniów oraz oocyty będące na różnych etapach oogenezy, natomiast w świetle jajowodów u obu samic stwierdzono owulujące oocyty. Ściana jajowodu składa się z trzech warstw: śluzowej, mięśniowej i surowiczej. W warstwie śluzowej stwierdzono 
występowanie komórek przypominających komórki klinowe, co nie było dotąd obserwowane u płazów beznogich. Pomimo obecności owulujących oocytów w żadnym rejonie jajowodu niezaobserwowano plemników, co pozostawia pytanie o występowanie magazynowania plemników u samic tego gatunku wciąż otwartym.

\section{Introduction}

Various aspects of the biology of caecilians (Gymnophiona) still remain poorly understood. Members of this group live in tropical regions of the southern hemisphere under the ground or in the water (Jared et al., 1990). Caecilians exhibit internal fertilization: males possess an introminent organ termed phallodeum (e.g., Tonutti, 1931), which penetrates the female's cloaca during copulation (Kupfer et al., 2006). Fertilization occurs in the anterior part of the oviduct (Wake, Dickie, 1998). Approximately two thirds of the species are oviparous, and the rest are viviparous (e.g., Wake, 1977; San Mauro et al., 2014).

The first descriptions of the female reproductive tract in Gymnophiona were provided by Müller (1832) and Rathke (1852). There have been an increasing number of studies describing the anatomy of the reproductive systems of caecilians including both phylogenetically basal oviparous [Ichthyophis supachaii Taylor, 1960 (Pewhom et al., 2015); I. beddomei Peters, 1880 (Masood-Parwees, Nadkarni, 1993); I. glutinosus Linnaeus, 1758; Siphonops annulatus Mikan, 1820 (Sarasin, Sarasin, 1887); Gegeneophis ramaswamii Taylor, 1964 (Beyo et al., 2007)] and derived viviparous species [e.g., Chthonerpeton indistinctum Reinhardt, Lütken, 1862 (Berois, De Sa, 1988); Typhlonectes compressicauda Duméril and Bibron, 1841 (Exbrayat et al., 1983)], but an understanding of the morphology, anatomy and function of these reproductive systems still lags behind that of anurans and caudates.

Typhlonectes natans Fischer In Peters, 1880 is an aquatic, viviparous caecilian that lives in rivers, swamps and lakes in the northern areas of South America (e.g., Fuhrmann, 1914). This species' range covers the Cauca and Magdalena rivers in Columbia and Lake Maracaibo in Venezuela (e.g., Fuhrmann, 1914). Its body has a length ranging from $45-55 \mathrm{~cm}$. Sexual dimorphism is manifested in body length (females are larger) and the shape of the cloaca (Kupfer, 2009).

The aim of this study was to describe for the first time the anatomy of the female reproductive tract of viviparous $T$. natans and to compare the results with the available literature of both oviparous and viviparous species. Special attention was paid to the histological structure of each part of the reproductive tract and the search for putative places of female sperm storage in the oviduct. We performed the research using light microscopy.

\section{Materials and methods}

We focused on two adult T. natans females from the Municipal Zoological Garden (Łódź, Poland). Individuals were assigned to a species on the basis of the number of lobes surrounding the vent and on the basis of genetic study. The two females were kept with two males in a 400-liter aquarium filled with 140 liters of water and a sandy bottom. The temperature of the water was electronically maintained at $26-27^{\circ} \mathrm{C}$. The animals were fed raw beef, earthworms and vitamins ad libitum. The total lengths of the females at the moment of sacrifice were 503 and $527 \mathrm{~mm}$.

The animals were killed via immersion in a $0.1 \%$ water solution of tricaine methanesulfonate, MS - 222 (Sigma $^{\circledR}$, St. Louis, MO, USA). After opening up the abdominal cavity, the reproductive tracts of the females were dissected (Figure 1). The materials were preserved in Bouin fixative 
for one week. Later, the material was dehydrated in a graded series of ethanol $(70 \%, 96 \%, 100 \%)$, cleared in toluene and embedded in Paraplast ${ }^{\circledR}$ Regular (Sigma ${ }^{\circledR}$, St. Louis, MO, USA). The obtained material was sliced on a microtome to create transverse sections 7 micrometers thick that were then affixed to slides. Selected slides were treated with Hematoxilin - Eosin (HE), Passini method and Mallory's trichrom for general cytology and with Alcian Blue \& Periodic Acid Schiff stain (AB+PAS) for histochemical cytology. After treatment, the slides were enclosed in a Thermo Scientific Shandon Consul Mount and observed using a light microscope. The slides were photographed using a Nikon COOLPIX P6000 camera. For each individual, approximately 150 slides were prepared representing the entire reproductive duct. Measurements of the structures were obtained using ImageJ software.

\section{Results}

The female reproductive tract of $T$. natans consisted of a pair of ovaries accompanied by twisted fat bodies, paired oviducts and the cloaca (Figure 1).

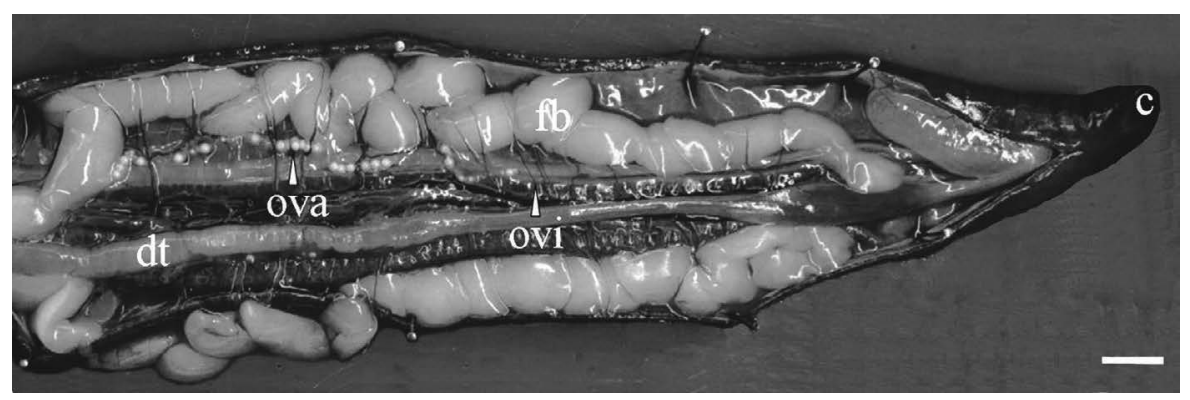

(c) cloaca; (dt) digestive track; (fb) fat bodies; (ova) ovary; (ovi) oviduct. Scale bar $=10 \mathrm{~mm}$.

Figure 1. Gross morphology of the female reproductive system of Typhlonectes natans

Oocytes at various stages of development were observed in the ovaries and in the oviducts of both females.

\section{Ovary and oocytes}

The ovaries of both individuals were approximately $90 \mathrm{~mm}$ in length and fewer than $3 \mathrm{~mm}$ in diameter. They were connected to the respective kidneys and fat bodies by a mesovarium.

The ovaries were surrounded by connective tissue and enveloped by peritoneal epithelium. Several germinal nests and oocytes in different stages of development (including previtellogenic, vitellogenic and postvitellogenic oocytes) were present inside the ovaries (Figure 2A), and they varied in size from $240-1,300 \mu \mathrm{m}$. The oogonia were grouped into germinal nests, which were arranged in a segmental manner (Figure 2B). These structures were oocytes inside of the ovary were separated by connective tissue, not surrounded by follicular cells. The germinal nests were situated between oocytes. 

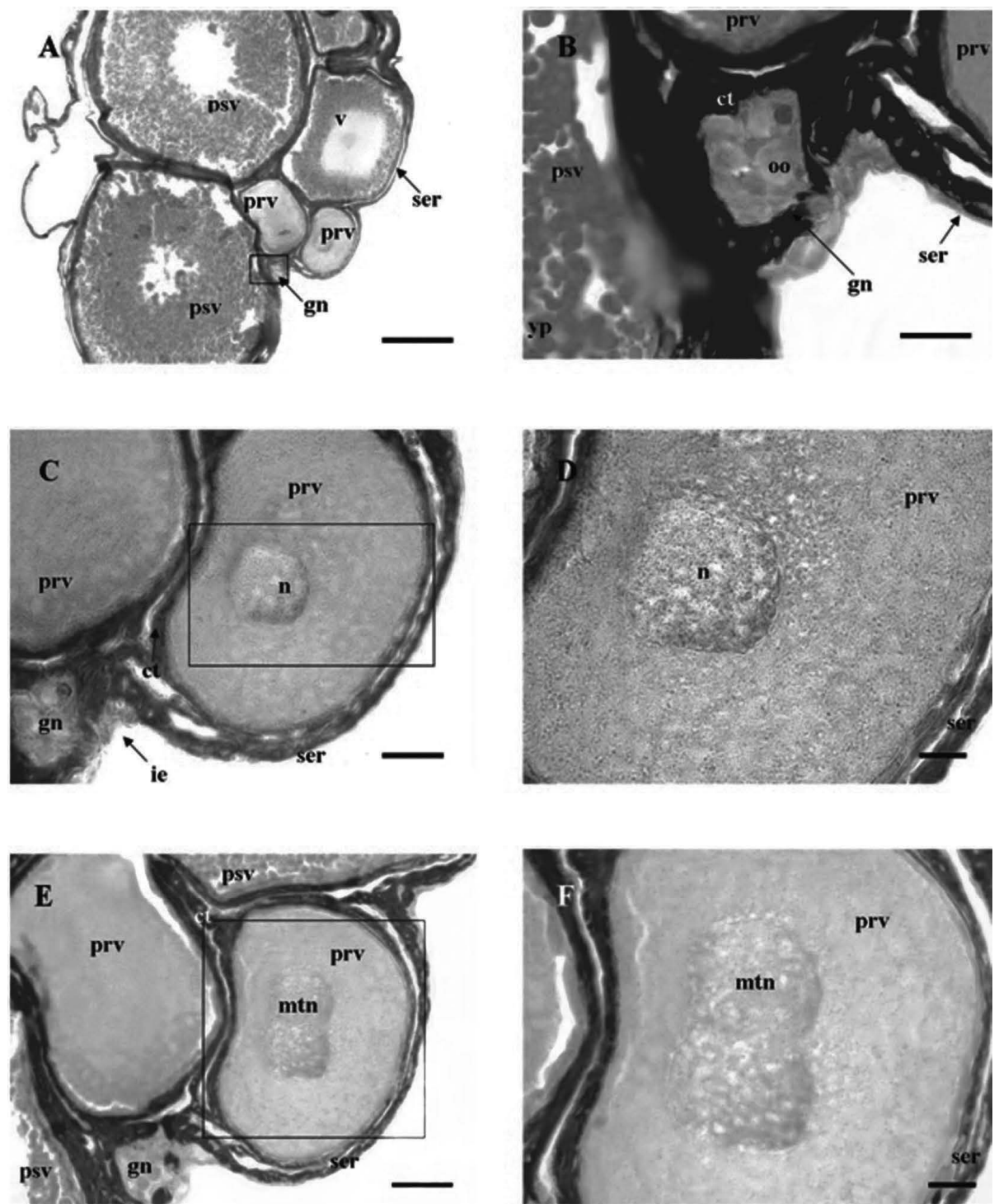

(A) gross structure (scale bar $=300 \mu \mathrm{m})$. (B) germinal nests of oogonia (scale bar $=20 \mu \mathrm{m})$. $(\mathrm{C}, \mathrm{D})$ previtellogenic cells with the eccentric nucleus (scale bar $\mathrm{C}=50 \mu \mathrm{m}, \mathrm{D}=30 \mu \mathrm{m}$ ). (E, F) previtellogenic cells with the multiple nuclei (scale bar $\mathrm{E}=50 \mu \mathrm{m}, \mathrm{F}=30 \mu \mathrm{m}$ ). (ct) conective tissue; (gn) germinal nests; (ie) islets of epithelium; (mtn) multiple nuclei; (n) nucleus; (oo) oocyte; (prv) previtellogenic oocyte; (psv) postvitellogenic oocyte; (ser) serosus membrane; (v) vitellogenic oocyte; (yp) yolk platelets.

Figure 2. Histological structure of the ovary of T. natans. Passini staining

Previtellogenic oocytes (Figure 2C-F) were found at the periphery of ovary, which implied that progressive ovarian zonation was present. These cells were surrounded by membrana granulosa of the ovary and a thin layer of connective tissue. The cell nucleus of a previtellogenic oocyte 
was spherical and relatively large compared with the entire cell (Figure $2 \mathrm{C}-\mathrm{D}$ ). The nucleus contained numerous nucleoi. In addition, multiplying of the number of nuclei in some oocytes was observed (Figure 2E-F). Previtellogenic oocytes did not contain supplementary material or pigment grains. In the late previtellogenic phase, the oocytes became larger and began to accumulate supplementary material such as platelets of yolk and lipid droplets. In this phase, the oocytes had clearly visible islets of glycoprotein materials.

Oocytes in the vitellogenic phase were easy to identify because they contained peripherally arranged platelets of heterogeneously sized yolks, which increased with later vitellogenic stages. Large and numerous yolk platelets were found in the cortical layer of the vitellogenic oocytes, as well as pigment grains, that had accumulated in the animal hemisphere. Interestingly, the theca cell layer was thicker in oocytes in the vitellogenic phase than in oocytes in the previtellogenic phase.

The postvitellogenic oocytes were the largest in size (approx. 1mm). The nuclei of the postvitellogenic cells were large and irregularly shaped. Furthermore, there were densely arranged platelets of yolk in the cytoplasm of postvitellogenic oocytes. The surface layer of the ooplasm contained cortical grains.

We observed the atresia of some developing follicles. Atresia was established on the basis of characteristic changes in the nucleus shape and degenerative changes of the oocytes. The nuclei of the artretic follicles were shrunken and had an irregular shape.

\section{Fat bodies}

The multi-lobed, leaf-like fat bodies were observed parallel to the reproductive tract of the studied females (Figure 1). They were extremely extensive (approximate width: $10 \mathrm{~mm}$ ) and they stood out in their size compared with other internal organs.

\section{Oviduct}

The length of the oviducts in both of the tested animals was approximately $140 \mathrm{~mm}$. The oviducts consisted of two morphological units: starting with the funnel, the anterior part with a larger lumen and a relatively thin layer of muscles (Figure 3A-B) and the rear part, the so-called pars uterine, which had a thick layer of muscle and lower lumen (Figure 3C-D). The oviduct wall had a layered structure with the mucous membrane lining the lumen, a layer of muscles and the external serous membrane (Figure 3). In the lumen of the oviduct, we found mucous aggregations as well as singular epithelial cells, especially in the pars uterina.

The mucous membrane consisted of a simple columnar epithelium (Figure 4A-D) composed of three types of epithelial cells: ciliated cells, unciliated secretion cells (Figure 4A-B) and a few wedge-like cells (Figure 4A). The epithelium formed numerous villus-like folds, which were directed into the oviduct lumen. On the top of these folds, a larger proportion of ciliated epithelial cells were visible (Figure 4B). The number and height of the folds of the mucous membrane depended on location within the oviduct; longer and more numerous folds occurred in its anterior part. Under the epithelium, a layer of connective tissue with numerous fibers was present (Figure 4A-B). 

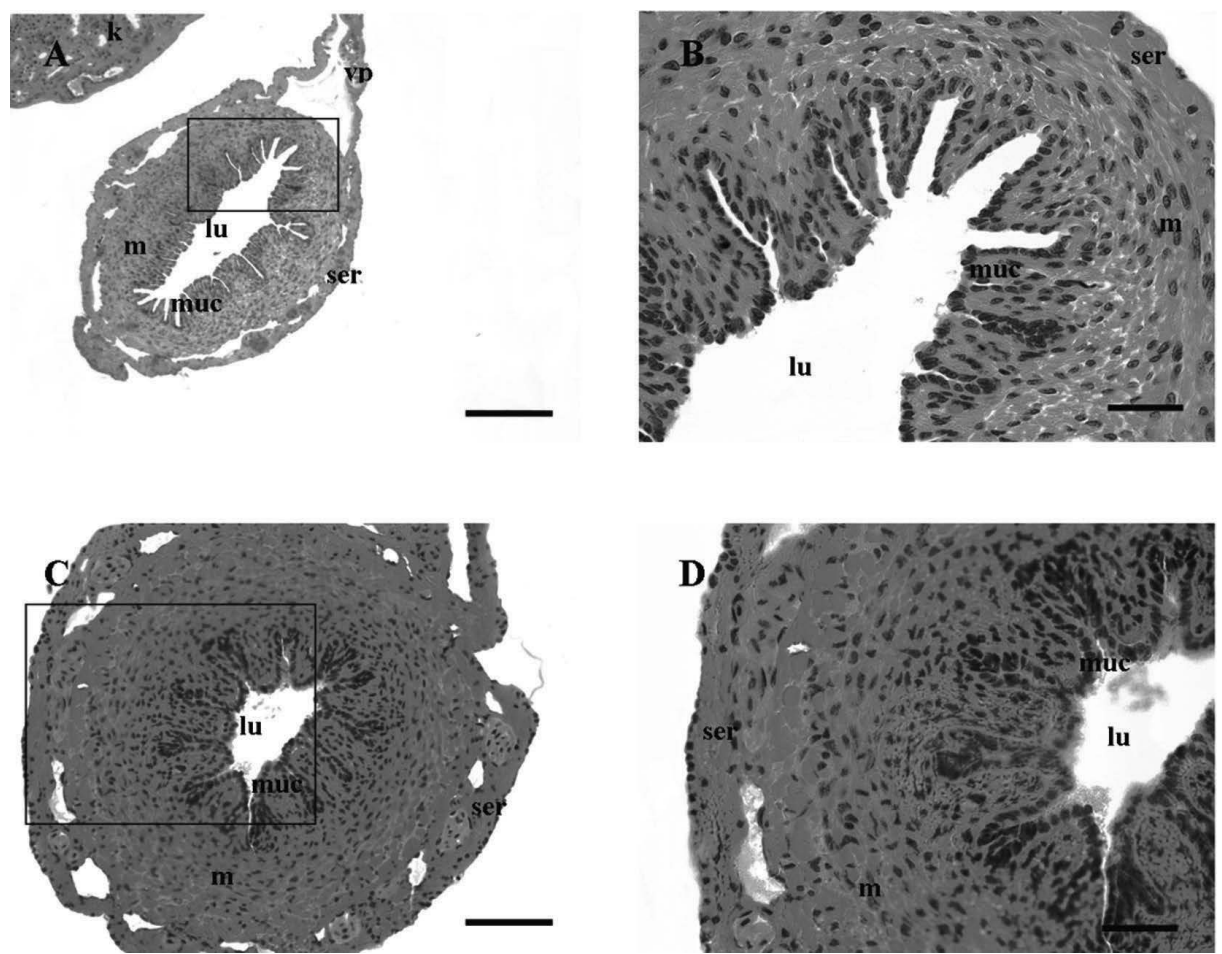

(A, B) front part of the oviduct (scale bar $\mathrm{A}=300 \mu \mathrm{m}, \mathrm{B}=50 \mu \mathrm{m}) .(\mathrm{C}, \mathrm{D})$ rear part of the oviduct, so-called pars pars uterina (scale bar $\mathrm{C}=100 \mu \mathrm{m}, \mathrm{D}=50 \mu \mathrm{m}$ ). Hematoxylin \& eosin staining. (k) kidney; (lu) lumen; (m) muscles; (muc) mucous membrane; (ser) serous membrane; (vp) visceral peritoneum.

Figure 3. Anatomical structure of the oviduct of T. natans

There was a layer of smooth muscles just below the mucous membrane (Figure 4C-D). The thickness of the muscle layers depended on the part of oviduct and, as noted above, the posterior part of the oviduct - the so-called "uterine" - had the thickest layer of muscles.

The outermost layer of the oviduct wall was a serous membrane. It consisted of connective tissue covered with visceral peritoneum (Figure 4C-D). Numerous blood vessels and elastic fibers were visible. Visceral peritoneum surrounded the oviduct and nearby located kidney.

The oviducts were highly extensible, which was clearly seen in slides containing the passing oocytes (Figure 4E-F). In such places, the walls of the oviduct wall were stretched, which rendered the mucous folds and muscular layers very thin.

The oocytes that were passing through the oviduct were unfertilized. Since these oocytes were filled with yolk platelets, they were in the postvitellogenic phase. 

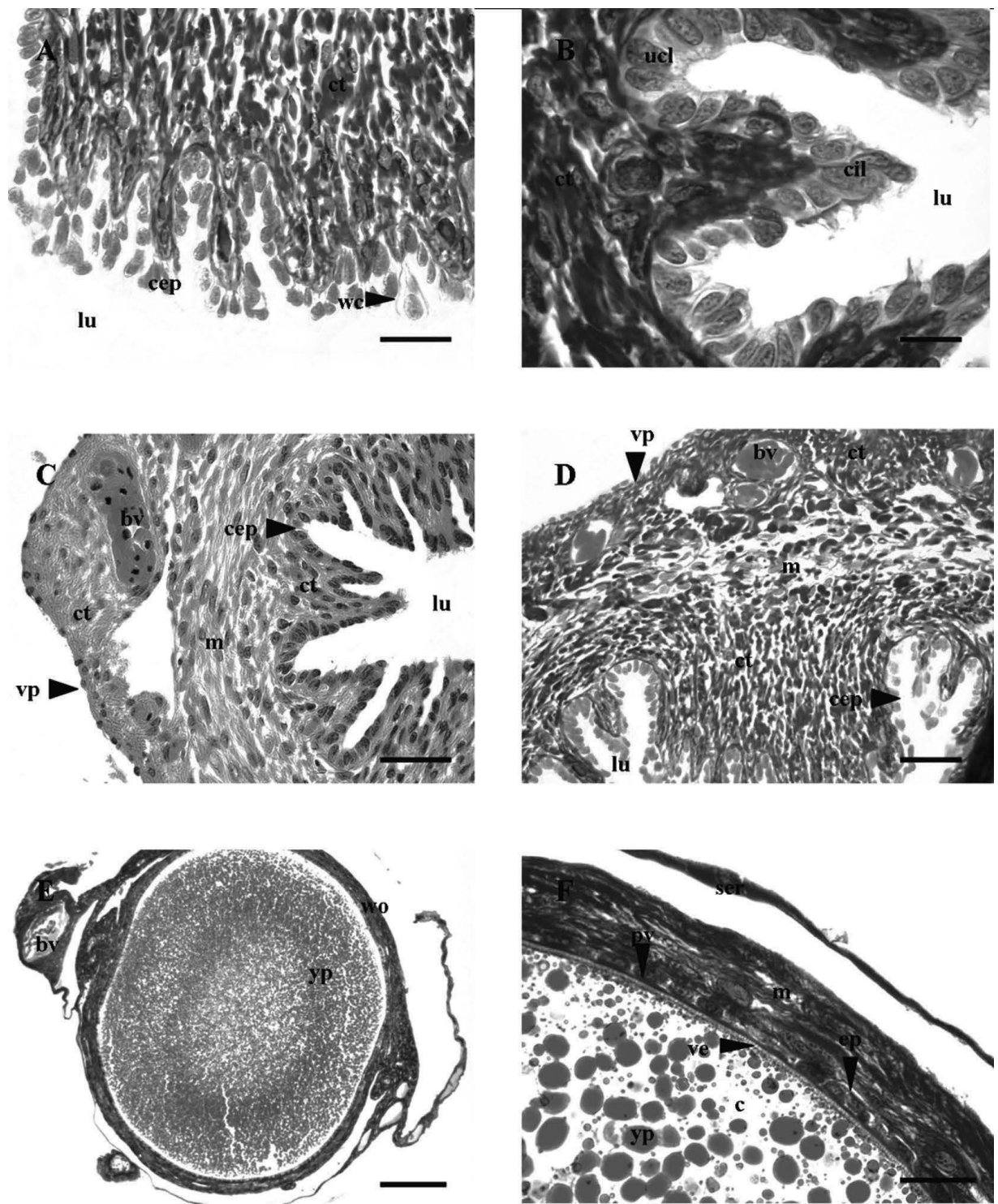

(A, B) mucous membrane of the wall of the oviduct (scale bar A $=30 \mu \mathrm{m}, \mathrm{B}=20 \mu \mathrm{m}$ ). (C, D) structure of the wall of the oviduct (scale bars $=50 \mu \mathrm{m}$ ). (E, F) mature oocyte passing through the oviduct (scale bar $\mathrm{E}=300 \mu \mathrm{m}, \mathrm{F}=30 \mu \mathrm{m})$. (A, B, D, F) Mallory's trichrome staining; (C) Hematoxilin - eosin staining; (E) Passini staining. (bv) blood vessel; (c) cytoplasm; (cep) cilindrincal epithelium; (cil) ciliated cell; (ct) connective tissue; (ep) epithelium; (lu) lumen; (m) muscles; (pv) previtelline space; (ser) serous membrane; (ucl) unciliated cell; (ve) vitelline envelope; (vp) visceral peritoneum; (wc) wedge like cell; (wo) wall of oviduct; (yp) yolk platelets.

Figure 4. Histological structure of the oviduct of T. natans 


\section{Cloaca}

The cloacal walls consisted of an epithelial layer, connective tissue and a layer of circular and longitudinal muscles (Figure 5A). The lumen of the cloaca was star-like (Figure 5A). Epithelium with connective tissue created mucosal folds, which projected into the lumen of the cloaca (Figure 5A). The folds were more branched in the anterior part of the cloaca than in the posterior part (Figure 5A-B). Because of this irregular branching, the lumen of the cloaca was tortuous. Stratified columnar epithelium formed the lining of the cloaca (Figure 5C-D). The epithelial cells possessed large nuclei and low levels of cytoplasm. We noted that the anterior part of the cloaca was lined with a thinner layer of epithelium than the posterior part (Figure 5C-D). The epithelium contained round secretion cells with medium-sized nuclei and abundant cytoplasm. The secretions of these cells could be stained with alcian blue (AB), which suggests that the mucus consisted of carboxylated glycosaminoglycans $(\mathrm{AB}+$ ) but lacked neutral carbohydrates (PAS-). A thin layer of mucus covered the walls of the cloaca (Figure 5C-D).
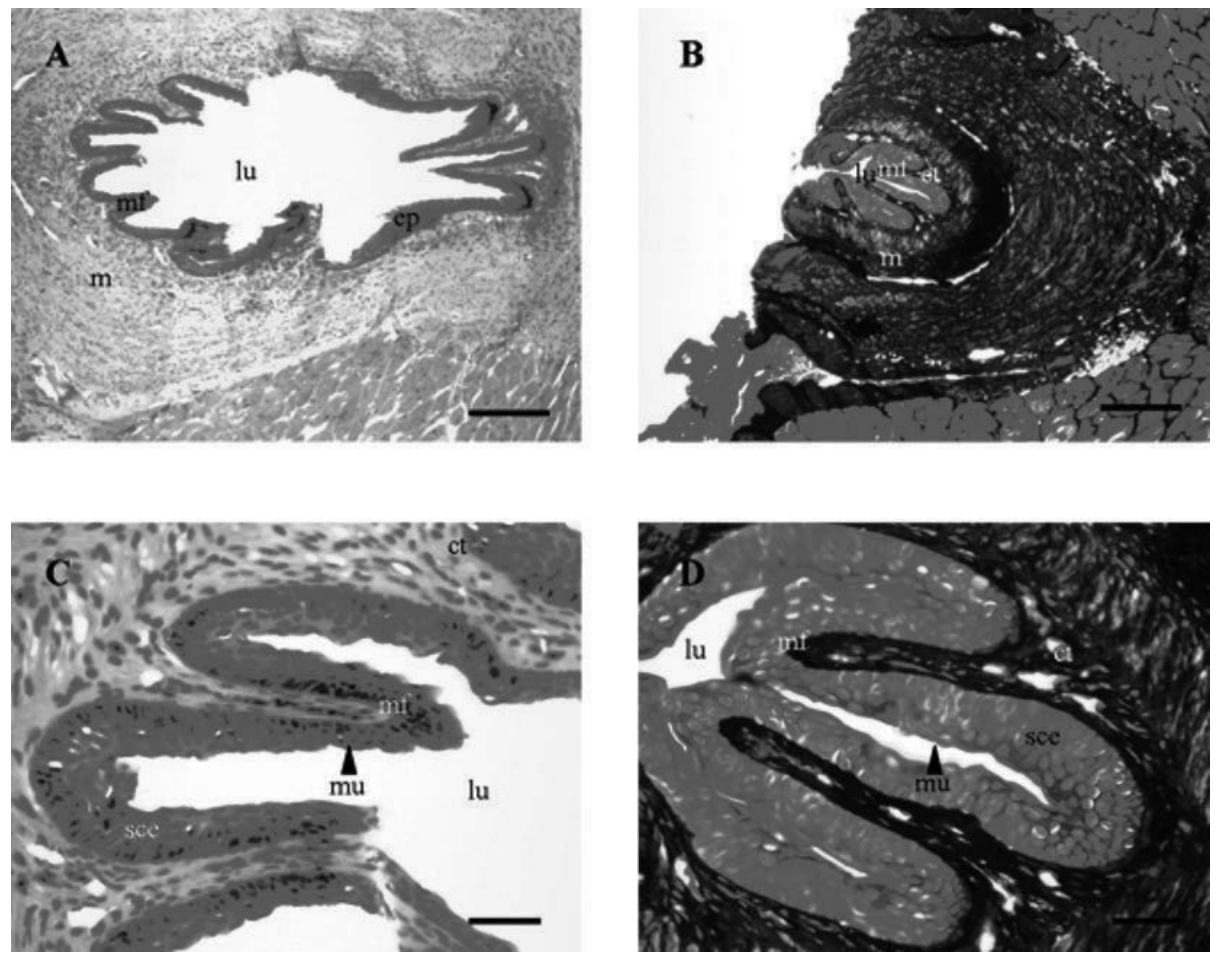

From the anterior part (A, C) to the posterior part (B, D) (scale bars A, B $=300 \mu \mathrm{m}, \mathrm{C}, \mathrm{D}=50 \mu \mathrm{m})$. (A, C) Hematoxilin - eosin staining; (B, D) Mallory`s trichrome staining. (ct) connective tissue; (lu) lumen; (m) muscle; (mf) mucosal fold; (mu) mucus; (ps) process of skin; (sce) stratified columnar epithelium.

Figure 5. Histological structure of the cloaca of T. natans 


\section{Discussion}

Presented study revealed, that female reproductive system of T. natans possess a similar organization as other previously described members of Gymnophiona [e.g., Hypogeophis rostratus (Oyama, 1952); Ch. indistinctum (Welsch et al., 1977), Dermophis mexicanus (Wake, 1980); T. compressicauda (Exbrayat, 1983, 1984, 1986, 1988, 1992, 1996) and I. cf. kohtaoensis (Kuehnel, Kupfer, 2012)]. Their anatomy consists of paired ovaries with attached fat bodies, paired oviducts and a cloaca.

The ovaries of viviparous T. natans were paired, elongated structures. Their length (approximately $90 \mathrm{~mm}$ in both of the studied individuals) was similar to that of $T$. compressicauda (Exbrayat, 2009), in which the ovaries of adult specimens were 60-100 mm in length. Fat bodies attached by connective tissue alongside the ovaries were observed. The lumen in ovaries was not detected. Originally, the occurrence of the lumen in the ovaries of Gymnophiona was reported by Tonutti (1931), but this phenomenon has not been confirmed more recently and is accordingly considered to be an artifact (Exbrayat, 2009). The ovaries consisted of germinal nests and oocytes in various stages of development: previtellogenic, vitellogenic and postvitellogenic. In amphibians, oogonia are organized into various structures: in anurans they are called germ patches (Masood-Parwees, Nadkarni, 1993), and in Urodela and Gymnophiona they are termed germinal nests (Gomes et al., 2012). The germinal nests of T. natans are arranged in a segmental manner as previously observed in T. compressicauda and oviparous I. beddomei (Masood-Parwees, Nadkarni, 1993; Exbrayat, 2006). In Ch. indistinctum (Berois, De Sa, 1988) and I. supachai (Pewhom et al., 2015), germinal nests are randomly scattered throughout entire ovary.

Roughly a dozen oocytes in different stages of development we observed in the oviducts of both of the studied T. natans females. This finding agrees with observations of other Gymnophiona in which the number of oocytes in the oviducts varied from 3-30. However, the number of oocytes also depends on the current reproductive phase of the animal; more oocytes are found in pregnant females than in non-pregnant ones (Exbrayat, 2009).

One of the general differences between oviparous and viviparous caecilians is that the oviducts of oviparous species are situated some distance from the ovaries; in viviparous species the funnel is in some distance from the ovary, and the oocytes are ovulated directly into the oviduct (Exbrayat, 2009), which was also confirmed in this study. The oviducts of oviparous species are typically divided into three regions: the pars recta, the pars convolute and the pars uterina (Exbrayat, 2009; Kuehnel, Kupfer, 2012); the oviducts of viviparous species are divided into two regions: anterior and posterior (Exbrayat, 2009). Our results confirmed this general rule since the oviducts of T. natans are clearly composed of two parts: the anterior part, with a large lumen and a thin layer of muscle, and the posterior part, pars uterina, characterized by a small lumen and a thick layer of muscles. These observations are similar to the results reported for other viviparous genera: Chthonerpeton (Parker, Dunn, 1964), Dermophis (Wake, 1980) and closely related T. compressicauda (Exbrayat, 1984, 1986, 1988, 2009). It is accepted that fertilization occurs in the anterior part of the oviduct, which also contains the glands that produce the mucous envelope of eggs (Exbrayat, 2009; Kuehnel, Kupfer, 2012).

The inner walls of $T$. natans oviducts consisted of folds partially filling the oviductal lumen. Anteriorly the folds contained a larger fraction of ciliated cells than other regions of the oviductal mucous membrane. There were no differences in the structure of the epithelium in the dorsal and abdominal parts of the oviduct. This finding is inconsistent with observations of oviparous I. supachaii in which the anterior and the middle parts of the oviduct consisted of two distinct epithelia: 
a simple columnar epithelium in the dorsal part and a ventral side lined with pseudostratified columnar epithelium (Pewhom et al., 2015). Interestingly, the epithelial folds in T. natans contain wedge-like cells, which not have been previously reported in caecilians (Oyama, 1952; Wake, 1970; Welsch et al., 1977; Gomes, 2012). Cells of this type are rare in the oviductal mucosa, which may explain the lack of information about their presence in other caecilians. The function of these wedge-like cells in the oviducts is unknown; they are likely immature secretion cells (Young et al., 2010). The second type of cells, which are found in the epithelium of the mucous membrane, are ciliated cells, and these cells enable active transport of secreted mucus alongside the oviduct via the undulating movements of cilia (Young et al., 2010). The third type of epithelial cells, the unciliated ones, are single-celled glands with an exocrine type of secretion.

Epithelial secretions of the oviduct can perform several functions. One of these functions may be to protect the oviduct walls against mechanical damage during the transportation of oocytes and fetuses. Epithelial secretions may also protect the oocytes from damage. Another important function of epithelium secretions in viviparous species is nutrition of fetuses. After the yolk stocks are depleted, fetuses scrape oviductal epithelium by fetal teeth and feeding on them (Wake, 1970). Wake (1970) described the enlargement of glandular areas that contained developing fetuses within the oviducts of Gymnopis multiplicata Peters, 1874. Welsch et al. (1977) noted that the oviductal epithelium of $C h$. indistinctum produces secretions rich in free amino acids and carbohydrates during the early stage of pregnancy. In the late stages of pregnancy, the material was rich in lipids (Welsch et al., 1977). Oviductal epithelial secretions can also create a barrier preventing sperm from traveling too far into the oviduct prior to ovulation by creating physiological demarcation line consisting of glandular secretions (Kuehnel, Kupfer, 2012). Mucus can create a specific biochemical environment around sperm and enable them to maintain their vitality for a long time; this time duration corresponds to the time that these cells are stored in females.

Oviductal wall stretching, described in Gymnophiona by Wake (1970), was also observed herein when oocytes of a diameter of $1 \mathrm{~mm}$ passed through. When large oocytes passed through the oviducts, the walls of the ducts became extremely thin and the mucosal folds were not visible. The muscle layer was much thinner than in other parts of the oviduct. After the passage of the oocyte, the oviductal wall returned to its previous shape and diameter.

The anatomy of the cloaca of $T$. natans exhibits numerous similarities with previously described viviparous species, but there were histochemical differences in mucus composition. The mucus of $T$. natans consists of carboxylated glycosaminoglycans (AB+), but lack neutral carbohydrates (PAS-). In the cloaca of I. supachaii, the mucus is reactive to AB and PAS, suggesting that this secretion is a mixture of neutral and acid mucopolysaccharides (Pewhom et al., 2015).

No sperm were noted in the oviducts of either of the examined T. natans females. This result is surprising since both females possessed ovulated eggs in their oviducts. Kuehnel and Kupfer (2012) reported that oviparous females of I. cf. kohtaoensis (Family: Ichthyophidae) store sperm between mucous folds of their oviducts. This finding implies that at least I. kohtaoensis does not possess specialized sperm storage organs, spermatheca, that are common in tailed amphibians (Urodela). At this time, we were unable to compare the location of sperm storage between oviparous and viviparous caecilians, but we nonetheless propose the hypothesis that females of viviparous taxa may store sperm in a similar way as oviparous species i.e., in spaces between mucous folds in the anterior part of the pars uterina. A lack of spermathecae and overall similarity in oviductal anatomy of viviparous T. natans and oviparous I. cf. kohtaoensis (Kuehnel, Kupfer, 2012), in which sperm storage was detected between the mucosal folds of the oviducts, allows us to 
formulate such a hypothesis. A possible explanation for the lack of sperm in the reproductive ducts of female T. natans is that long-term sperm storage might not occur, most likely as a consequence of viviparity or a more simply the females have been sacrificed prior copulations. However it cannot be excluded that the lack of sperm was a consequence of captivity conditions, which for unknown reasons may prevent copulations.

\section{Acknowledgements}

We thank K. Żuwała for useful comments on the manuscript, D. Podkowa for her help in preparing the slides and S. Hofman for genetic confirmation of species assessmen. The work was partly supported by K/ZDS/005401 grant from Jagiellonian University and PhD Students Society of Jagiellonian University for Jakub Dymek.

\section{References}

Berois, N., de Sá, R. (1988). Histology of the ovaries and fat bodies of Chthonerpeton indistinctum. Journal of Herpetology, 22, 146-151.

Beyo, R.S., Sreejith, P., Divya, L., Oommen, O.V., Akbarsha, M.A. (2007). Ultrastructural observations of previtellogenic ovarian follicles of the caecilians Ichthyophis tricolor and Gegeneophis ramaswamii. Journal of Morphology, 268, 329-342.

Exbrayat, J.M., Collenot, G., Allizard, F., Laurent, M. (1983). Quelques aspects de l'évolution de l'ovaire de Typhlonectes compressicaudus (Duméril et Bibron, 1841), Batracien Apode vivipare. - Etude quantitative et histochimique des corps jaunes. Reproduction Nutrition Development, 23 (5), 889-898.

Exbrayat, J.M. (1984). Quelques observations sur l'évolution des voies génitales femelles de Typhlonectes compressicaudus (Duméril et Bibron, 1841), Amphibien Apode vivipare, au cours du cycle de reproduction. Comptes Rendus de l Académie des Sciences - Series III - Sciences de la Vite, 298 (1), 13-18.

Exbrayat, J.M. (1986). Le testicule de Typhlonectes compressicaudus; structure, ultrastructure, croissance et cycle de reproduction.Mémoires de la Société zoologique de France, 43, 121-132.

Exbrayat, J.M. (1988). Variations pondérales des organes de réserve (corps adipeux et foie) chez Typhlonectes compressicaudus, Amphibien Apode vivipare, au cours des alternances saisonnières et des cycles de reproduction. Annales des sciences naturelles. Zoologie et biologie animale, 9 (1), 45-53.

Exbrayat, J.M. (1992). Appareils génitaux et reproduction chez les Amphibiens Gymnophiones. Bulletin de la Société zoologique de France, 117 (3), 291-296.

Exbrayat, J.M. (1996). Croissance et cycle du cloaque chez Typhlonectes compressicaudus (Duméril et Bibron, 1841), Amphibien Gymnophione. Bulletin de la Société zoologique de France, 121 (1), 93-98.

Exbrayat, J.M. (2006). Reproductive biology and phylogeny of Gymnophiona: Caecilians. Boca Raton: CRC Press.

Exbrayat, J.M. (2009). Oogenesis and female reproductive system in amphibia-Gymnophiona. In: M. Ogielska (ed.), The reproductive biology of amphibians (pp. 305-344). Enfield, NH Science Publishers.

Exbrayat, J.M., Collenot, G., Allizard, F., Laurent, M. (1983). Quelques aspects de l'évolution de l'ovaire de Typhlonectes compressicaudus (Duméril et Bibron, 1841), Batracien Apode vivipare. - Etude quantitative et histochimique des corps jaunes. Reproduction, Nutrition, Development, 23 (5), 889-898.

Fuhrmann, O. (1914). Le Gene Typhlonectes. Mémoires de la Société des Sciences Naturelles de Neuchatel Neuchâtel, 5, 112-138. 
Gomes, A., Moreira, R., Navas, C., Antoniazzi, M., Jared, C. (2012.) Review of the reproductive biology of Caecilians (Amphibia, Gymnophiona). South American Journal of Herpetology, 7 (3), 191-212.

Hedges, S.B., Nussbaum, R.A., Maxson, L.R. (1993). Caecilian phylogeny and biogeography inferred from mitochondrial DNA sequences of the 12S rRNA and 16S rRNA genes (Amphibia: Gymnophiona). Herpetological Monographs, 64-76.

Jared, C., Navas, C.A., Toledo, R.C. (1999). An appreciation of the physiology and morphology of the Caecilians (Amphibia: Gymnophiona). Comparative Biochemistry and Physiology Part A: Molecular \& Integrative Physiology, 123 (4), 313-328.

Kuehnel, S., Kupfer, A. (2012). Sperm storage in caecilian amphibians. Frontiers in Zoology, 9 (1), 12.

Kupfer, A. (2009). Sexual size dimorphism in caecilian amphibians: analysis, review and directions for future research. Zoology, 112, 362-369.

Kupfer, A., Kramer, A., Himstedt, W., Greven, H. (2006). Copulation and egg retention in an oviparous Caecilian (Amphibia: Gymnophiona). Zoologischer Anzeiger, 244, 223-228.

Masood-Parweez, U., Nadkarni, V.B. (1993). Morphological, histological and histochemical studies of the ovary of an oviparous caecilian, Ichthyophis beddomei (Peters). Journal of Herpetology, 27 (1), 63-69.

Müller, J. (1832).Beiträge zur Anatomie und Naturgeschichte der Amphibien. I. Ueber die natürliche Eintheilung der Amphibien. Zeitschrift für Physiologie, 4, 195-275.

Oyama, J. (1952). A microscopical study of the visceral organs of a Gymnophiona, Hypogeophis rostratus. Kumamoto Journal of Science. Series B. Biology and geology, 1, 117-125.

Parker, H.W., Dunn, E.R. (1964). Dentitional metamorphosis in the Amphibia. Copeia, 1964, 75-86.

Pewhom, A., Chumnanpuen, P., Muikham, I., Chatchavalvanich, K., Srakaew, N. (2015). Microscopic structures of the ovary and female genital ducts of Supachai's caecilian, Ichthyophis supachaii Taylor, 1960 (Amphibia: Gymnophiona). Acta Zoologica, 97 (4), 454-463.

Rathke, H. (1852). Bemerkungen über mehrere Körpertheile der Caecilia annnulata. Archiv für Anatomie und Physiologie von J. Müller, 335-349.

San Mauro, D., Gower, D.J., Müller, H., Loader, S.P., Zardoya, R., Nussbaum, R.A., Wilkinson, M. (2014). Life-history evolution and mitogenomic phylogeny of caecilian amphibians. Molecular Phylogenetics and Evolution, 73, 177-189.

Sarasin, P., Sarasin, F. (1887). Ergebnisse naturwissenschaftlicher Forschungen auf Ceylon: Zur Entwicklungsgeschichte und Anatomie des Ceylonischen Blindwühle Ichthyophis glutinosus L. Epicrium glutinosum. C.W. Kreidel's Verlag. Wiesbaden.

Spengel, J.W. (1876). Das Urogenitalsystem der Amphibien: Der anatomische Bau des Urogenitalsystems. Stahl. Würzburg.

Tonutti, E. (1931). Contribution to the knowledge of Gymnophiona. XV. The genital system. Morphologisch Jahrbücher, 68, 151-292.

Wake, M.H. (1970). Evolutionary morphology of the caecilian urogenital system. Part II. The kidneys and urogenital ducts. Acta Anatomica, 75, 321-358.

Wake, M.H. (1977). The reproductive biology of caecilians: an evolutionary perspective. In: The reproductive biology of amphibians. M. Ogielska (ed.). Springer US (pp. 73-101).

Wake, M.H. (1980). Reproduction, growth, and population structure of the Central American caecilian Dermophis mexicanus. Herpetologica, 244-256.

Wake, M.H., Dickie, R. (1998). Oviduct structure and function and reproductive modes in amphibians. Journal of Experimental Zoology, 282 (4-5), 477-506. 
Welsch, U., Müller, W., Schubert, C. (1977). Electronmicroscopical and histochemical observations on the reproductive biology of viviparous caecilians (Chthonerpeton indistinctum). Zoologische Jahrbucher. Abteilung für Anatomie, 97, 532-549.

Young, J.Z. (1981). The Life of Vertebrates, third ed. New York: Oxford University Press.

Young, B., Lowe, J.S., Stevens, A., Heath, J.W. (2006). Wheater's functional histology: a text and color atlas, fifth ed. Edinburgh: Churchill Livingstone.

Cite as: Dymek, J., Dymek, A., Osikowski, A. (2018). Anatomy of the female reproductive system and sperm storage of the viviparous caecilian Typhlonectes natans (Gymnophiona: Typhlonectidae). Acta Biologica, 25, 19-31. DOI: 10.18276/ab.2018.25-02. 